\title{
GJB2 and GJB6 genes mutations in children with non-syndromic hearing loss
}

\section{Mutaţiile genelor GJB2 si GJB6 la copiii cu surditate neurosenzorială non-sindromică}

\author{
Călin Lazăr ${ }^{1, *}$, Radu Popp ${ }^{2}$, Camelia Al-Khzouz ${ }^{1}$, \\ Gheorghe Mihuț ${ }^{3}$, Paula Grigorescu-Sido ${ }^{1}$ \\ 'Department of Paediatrics I, University of Medicine and Pharmacy ,,Iuliu Hațieganu” Cluj-Napoca, \\ Romania, \\ 2Department of Medical Genetics, ,,Iuliu Hațieganu” University of Medicine and Pharmacy, \\ Cluj-Napoca, Romania \\ ${ }^{3}$ Service of Otolaryngology, Clinical Emergency Paediatric Hospital, Cluj-Napoca, Romania
}

\begin{abstract}
Introduction. At the moment there is not enough data in Romania about the incidence of the main genetic mutations which can cause hearing loss.

Objective. The current research aims to determine on a representative sample the prevalence of two mutations of genes GJB2-c.35delG and p.W24X-and two mutations of genes GJB6-del(GJB6-D13S1830), del(GJB6-D13S1854) respectively - in patients with congenital nonsyndromic sensorineural hearing loss (CNSHL).

Methods: The sample group included 179 children with CNSHL. The evaluation consist in: a.Clinical, laboratory and imagistic examination; b.ENT exam and audiological evaluation. c.Two methods (semi-nested PCR technique followed by RFLP, validated with ARMS-PCR analysis) for detection of c.35delG and pW24X mutations; d.PCR-multiplex technique for detecting del(GJB6-D13S1830) and del (GJB6-D13S1854).

Results: The audiological diagnosis was: profound hearing loss in 116 patients (64.8\%), severe hearing loss in 29 children (16.2\%) and moderate hearing loss in 34 patients (representing 19\% of the trial patients). The prevalence for the three mutations was: $27.3 \%$ for c.35delG, $3.6 \%$ for p.W24X and 0.28\% for del(GJB6-D13S1830). The detection of the three mutations (two on GJB2 gene and one on GJB 6 gene) has allowed to establish the genetic cause for deafness in 45 patients, representing $25.14 \%$ of the sample group. Our study is reporting the first case in Romania with a mutation of gene GJB6. Mutation del(GJB6-D13S1854) lacked in all 179 patients.

Conclusion: The prevalence data obtained in the current research are comparable to data communicated by studies from other European countries.
\end{abstract}

Keywords: connexin 26 and 30, GJB2 mutation, GJB6 mutation, sensorineural hearing loss.

* Corresponding author: Călin Lazăr, Department of Paediatrics I, University of Medicine and Pharmacy „Iuliu Hațieganu", 68 Motilor Street, Cluj-Napoca, Romania, e-mail: calinlazar2004@yahoo.com

The first two authors have equally contributed to this work. 


\section{Rezumat}

Introducere: La momentul actual în România există date insuficiente despre incidența principalelor mutații genetice care pot cauza deficiențe de auz.

Obiectiv: Studiul de față și-a propus să analizeze (pe un lot de pacienți cu surditate congenitală non-sindromică reprezentativ statistic) prevalența a două mutații -c.35delG și p.W24X-ale genei GJB2 și prevalența a două mutații -del(GJB6-D13S1830) și del(GJB6-D13S1854) la nivelul genei GJB6.

Metodă: Lotul a cuprins 179 copii cu surditate congenitală non-sindromică. Evaluarea a constat în: a. Examen clinic, examinări de laborator și imagistică; $b$. Examen ORL și evaluare audiologică; $c$. Detectarea mutațiilor c.35delG și $\mathrm{pW} 24 X$ prin două tehnici (semi-nested PCR validată de analiza RFLP și ARMS-PCR); d. Identificarea mutațiilor del(GJB6-D13S1830) și del (GJB6-D13S1854) prin folosirea tehnicii PCR-multiplex.

Rezultate: Diagnosticul audiologic a fost: surditate profundă la 116 pacienți (64.8\%), surditate severă la 29 copii (16.2\%) și hipoacuzie moderată la 34 pacienți (19\% din totalul lotului). Prevalența mutațiilor a fost de $27.3 \%$ pentru c.35delG, $3.6 \%$ pentru p.W24X şi $0.28 \%$ pentru del(GJB6-D13S1830). Studiul nostru raportează primul caz din România cu mutație la nivelul genei GJB6. Detectarea celor trei mutații (două pe gena GJB2 și una pe gena GJB6) a permis stabilirea cauzei genetice a surdității la 45 pacienți (25.14\% din totalul lotului). Mutația del (GJB6-D13S1854) nu a fost detectată la niciun pacient.

Concluzie: Datele de prevalență obținute de prezenta cercetare sunt comparabile cu cele comunicate de studiile din alte țări europene.

Cuvinte cheie: conexinele 26 și 30, mutațiile GJB2, mutațiile GJB6, surditate neurosenzorială.

Received: 30 th August 2016; Accepted: 29 ${ }^{\text {th }}$ November 2016; Published: $14^{\text {th }}$ January 2017

\section{Introduction}

Connexins are transmembrane proteins that assemble to form gap junctions between neighbouring cells. There are two types of connexins: $\alpha$ (GJA) and $\beta$ (GJB) variably distributed in tissues. Sensorineural deafness occurs in 1/350-1/1000 newborns and $70 \%$ of these cases are genetic (1). It was two decades ago that connexins were found to be involved in genetic deafness, when locus DFNB1 has been identified on 13q11 chromosome. Most of the nonsyndromic inherited deafness $(60-80 \%$ of cases) is associated with mutation of the genes encoding connexins 26, 30, 31, 32, 43. Most frequent $(40-60 \%)$ are the mutations located in the $D F N B 1$ locus, more specifically $G J B 2$ gene (13q11-q12) encoding connexin 26, and GJB6 gene (13q12) encoding connexin 30 .

A large number of mutations have been identified on gene GJB2 and most of them $(85 \%)$ have been passed down through in an autosomal recessive manner. The frequency of these mutations is dissimilar depending on the population groups subjected to research. Most frequent are: c.35delG in Caucasians, c. 235 delC in Asians, $p . W 24 X$ in Asians and Central Europe Caucasians.

Different mutations on gene GJB6 were reported of which deletions (GJB6-D13S1830 and GJB6-D13S1854) - were detected with a high frequency in Hispanic people. Mutations $G J B 2$ and GJB6 may cause deafness both in homozygous and in compound heterozygous forms (two different mutations on the two alleles). Mutations of genes located in locus DNFB 1 affect communication between cells at the level of the inner ear and disturb the transformation of the mechanical signal into electrical signal. The phenotype determined by these mutations is a severe or profound bilateral and symmetrical hypoacusis.

Romania has a demographic hallmark, beeing the only Latin country from the Eastern and Central Europe. This feature may affect the occurrence of genetic mutations that are specific to certain populations. In extension to 
our previous study (2), the current research aims to determine the prevalence of two mutations of genes GJB2 -c.35delG and p.W24X- and two mutations of genes GJB6-del(GJB6D13S1830), del (GJB6-D13S1854) respectively - in patients with congenital nonsyndromic sensorineural hearing loss (CNSHL).

\section{Material and method}

The sample group included 179 children (68 boys and 111 girls) with congenital NSHL admitted in the Emergency Clinical Hospital for Children from February 2008 to December 2014. This group included the 75 children with hearing impairment presented in our previous research (2). The children were aged between 6 months and 18 years old, and were divided in the following groups: 6 months-1 year (4 patients), 1 to 3 years (8 patients), 3 to 7 years (21 patients) and 7 to 18 years (146 patients). Following the same protocol as in our previous research (2) the inclusion criteria were: a. congenital nonsyndromic sensorineural deafness diagnosis; b. absence of potential sibling relationships between patients included in the trial (anamnestic family tree for at least three generations). In the same manner were excluded from the study: a. secondary hearing loss cases (meningo-encephalitis, mastoiditis, posterior fossa tumors); b. patients with congenital syndromic hearing loss; c. cases with previous ototoxic treatments. The Ethics Board of the University of Medicine and Pharmacy "Iuliu Hațieganu“ Cluj-Napoca approved the study protocol (document no. 91/2006). For all patients undergoing audiological and genetic evaluation, the written consent was obtained according to the World Medical Association Declaration of Helsinki, revised in 2000 (Edinburgh).

In the first three steps the working method was identical to our previous study (2): a.Anamnesis (identifying history of ototoxic treatments or diseases inducing secondary hearing loss); b.Complete ENT examination and audiological examinations: otoscopy, tympanogram, acoustic otoemission -TOAEand tonal audiogram or (for patients unable to cooperate) auditory evoked potentials; c.Clinical examination, laboratory and imaging examinations (this step excluded syndromic deafness cases). The next phase of the research consisted in: d.Two methods (semi-nested PCR technique followed by RFLP, validated with ARMS-PCR analysis) for detection of c.35 delG and $p W 24 X$ mutations; e.PCR-multiplex technique for detecting $\operatorname{del}(G J B 6-D 13 S 1830)$ and del (GJB6-D13S1854).

Genotyping. DNA was extracted from peripheral blood leukocytes using a commercially available kit (Wizard Genomic DNA Purification Kit, Promega, Madison, USA). For the detection of GJB2 c.35delG mutation a semi-nested PCR-RFLP method was used (3). Using the primers $167 \mathrm{~F}$ and $452 \mathrm{R}$ a fragment of $285 \mathrm{bp}$ was obtained in the first PCR reaction. In the second PCR reaction, with the primers $167 \mathrm{~F}$ and 35DG, an 87 bp fragment was amplified by using $1 \mu 1$ of the amplicons solution obtained in the first round of amplification. $10 \mu 1$ of the PCR product of the second round of amplification was digested with the restriction enzyme EcoNI (ThermoFisherScientific, MA, USA). The wildtype allele fragment remains uncut, whereas the 35 delG mutation creates a restriction site for EcoNI. A PCR-RFLP based method (4) was used also for $\mathrm{p}$.W24X mutation detection. The results obtained by RFLP methods were validated with an ARMS-PCR method described by Scott et al (5). GJB6 gene was screened for del(GJB6D13S1830) and del(GJB6-D13S1854) by amplification in a single multiplex PCR assay of the breakpoint junction of each deletion and a segment containing GJB6 exon 1, which is used as an amplification control as described 
by delCastillo et al.(6). The PCR amplifications were carried out with Biometra PCR machine and a GeneAmpPCR System 9700 (Applied Biosystems ${ }^{\circledR}$, Life Technologies, USA). For the PCR products migration in $2.5 \%$ Metaphor agarose gel electrophoresis (Cambrex Bio Science Rockland, Inc.), staining with ethidium bromide and visualisation with UV light transilluminator (Vilber-Lourmat, Marne-laVallée, France) were identical as in our previous research (2).

Depending on the threshold mean in air conduction in the $500 \mathrm{~Hz}, 1000 \mathrm{~Hz}, 2000 \mathrm{~Hz}$ and $4000 \mathrm{~Hz}$ frequencies, hearing loss has been classified into: profound (91-120dB), severe (71$90 \mathrm{~dB})$, moderate $(41-70 \mathrm{~dB})$ and mild $(21-40 \mathrm{~dB})$ hearing loss. For statistical calculations of sample lot size we used Epi.Info 3.5.1. (2008) Programme and Java Applets for Power and Sample Size [Computer software Lenth, R. V. (2006-9).]

\section{Results}

By excluding any associate changes, the clinical examination and paraclinical (laboratory and imaging) results allowed - in all 179 patients included in the current study- the diagnosis of nonsyndromic sensorineural deafness.

At the ENT examination all 179 patients presented normal tympanic membrane. For all patients included in the study the audiological examination revealed normal (type A) tympanogram and bilateral absence of acoustic otoemission signals.

Table 1 presents the results of tonal audiogram or (for patients unable to cooperate) auditory evoked potentials.

Results of genetic testing for the 2 mutations analysed for gene GJB 2 can be found in Table 2.

All 40 homozygous and the 4 compound heterozygous patients developped profound or severe hearing loss. The genotype-fenotype correlation indicated the following: $33(82,5 \%)$ from the 40 homozygous patients had profound deafness and the other $7(17,5 \%)$ had severe hearing loss. Of the 4 compound heterozygous patients, 3 showed profound deafness and 1, severe hearing loss.

Distribution of alleles c.35delG and p.W24X is reflected in Table 3 .

We have identified a single case of mutation of the GJB6 gene, which presented a heterozygote genotype c.35delG/del(GJB6-D13S1830) and profound bilateral deafness. Frequency of mutation $\operatorname{del}(G J B 6-D 13 S 1830)$ is $0.28 \%(1 / 358$ of tested alleles).

By analysing the four mutations (two on GJB2 gene and two on GJB 6 gene) allowed us to establish the genetic cause for hearing loss in 45 patients, representing $25.14 \%$ of the sample group). 40 patients have presented a homozygote genotype c.35delG $(\mathrm{n}=38)$, p.W24X $\quad(\mathrm{n}=2)$ respectively. The other 5 patients presented a compound heterozygous genotype c.35delG/p.

Table 1. Results of tonal audiogram/auditory evoked potentials in 179 patients

\begin{tabular}{lcccccc}
\hline $\begin{array}{l}\text { Form of } \\
\text { sensorineural } \\
\text { hearing loss }\end{array}$ & \multicolumn{2}{c}{ Tonal audiogram } & \multicolumn{2}{c}{ Auditory evoked potentials } & \multicolumn{2}{c}{ TOTAL PATIENTS } \\
\cline { 2 - 7 } & $\begin{array}{c}\text { Limits } \\
\text { (dB) }\end{array}$ & $\mathbf{n}$ & $\begin{array}{c}\text { V wave } \\
\text { threshold (dB) }\end{array}$ & $\mathbf{N}$ & $\mathbf{n}$ & $\%$ \\
\hline Profound & $95-120$ & 89 & $>90$ & 27 & 116 & 64.8 \\
\hline Severe & $71-90$ & 23 & $71-90$ & 6 & 29 & 16.2 \\
\hline Moderate & $41-70$ & 30 & $40-70$ & 4 & 34 & 19 \\
\hline TOTAL & - & $\mathbf{1 4 2}$ & - & 37 & $\mathbf{1 7 9}$ & $\mathbf{1 0 0}$ \\
\hline
\end{tabular}


Table 2. GJB2 genotypes present in patients with NSHL

\begin{tabular}{|c|c|}
\hline Genotypes & Unrelated families $(n=179)$ \\
\hline A. $c .35 \mathrm{del} / \mathrm{c} .35 \mathrm{delG}$ & 38 \\
\hline B. c.35delG/p.W24X & 4 \\
\hline C. p.W24X/p.W24X & 2 \\
\hline Total A-C & $44(24.6 \%)$ \\
\hline D. c.35delG/ - & 18 \\
\hline E. p.W24X/- & 5 \\
\hline $\begin{array}{c}\text { Total D-E } \\
\end{array}$ & $23(12.8 \%)$ \\
\hline TOTALA-E & $67(37.4 \%)$ \\
\hline
\end{tabular}

Table 3. The distribution of $c .35 \mathrm{del} G$ and $p . W 24 X$ mutant alleles in analyzed patients with NSHL

\begin{tabular}{llccc}
\hline & 179 HCNNS patients from 179 unrelated families \\
\hline Mutation & Mutant alleles & \multicolumn{3}{c}{ Genotype $^{*}$} \\
\cline { 3 - 5 } & & Homozygote & Heterozygote & $\begin{array}{c}\text { Compound } \\
\text { Heterozygote } \\
\text { c.35delG/p.W24X }\end{array}$ \\
\hline c.35delG & $98 / 358$ & $38^{* * / 179}$ & $22 / 179$ & \\
& $(27.3 \%)$ & $(21.2 \%)$ & $(12.3 \%)$ & $4 * / 179$ \\
$\boldsymbol{p} . \boldsymbol{W}$ 24X & $13 / 358$ & $2^{* * / 179}$ & $9 / 179$ & $(2.2 \%)$ \\
& $(3.6 \%)$ & $(1.1 \%)$ & $(5 \%)$ & - \\
\hline Total & $\mathbf{1 1 1 / 3 5 8}$ & - & - & \\
& $\mathbf{( 3 1 \% )}$ & - & & \\
\hline
\end{tabular}

$* 179$ unrelated genotypes $=358$ unrelated alleles

** patients with profound or severe bilateral hypoacusis

W24X (n=4), respectively c.35delG/del GJB6$\operatorname{D1} 31830(\mathrm{n}=1)$.

\section{Discussions}

$D F N B 1$ locus situated on the 13q11-q12 chromosome includes genes $G J B 2$ and $G J B 6$ which encode connexins 26 and 30, respectively. These proteins are mutually conditioned both in terms of localization and expression. Inside the cochlea, the two connexins form heterometric "gap" junctions that unmistakably contribute to the upkeeping of cochlear homeostasis. The mutations of the two genes (as homozygote or compound heterozygote) affect the activities of the "gap" junctions and thus prevent the transformation of the mechanical signal into electrical signal. Deafness thus installed is bilateral and symmetrical, most often profound or severe.

The four mutations known at the level of gene GJB6 responsible for the occurrence of nonsyndromic sensorineural deafness are recessive deletions. In most cases of deafness, $G J B 6$ recessive mutations occur in association with mutations of $G J B 2$, which is justified by 
the neighbouring position of the two genes and their co-expression. Most frequently described are del(GJB6-D13S1830) and del(GJB6D13S1854), which truncate gene GJB6. Rodriguez -Paris et al. (7) have demonstrated that the del(GJB6-D13S1830) deletion causes hearing loss due to an allele-specific lack of GJB2 $m R N A$ expression and not as a result of dysgenic inheritance. The authors have reported that $\operatorname{del}(G J B 6-D 13 S 1830)$, disrupts human GJB2 expression at the transcriptional level in an allelespecific manner, presumably by removing one or more cis-regulatory elements located within the deleted region (7). Each of the two deletions determines the formation of an unfunctional 26 connexin and sensorineural hearing loss.

As we have mentioned 6 years ago in our previous study (2), in Romania there is no national medical track for congenital nonsyndromic deafness. For this reason, the exact number of CNSHL patients is not known. The 179 patients in our trial were born between 1994 and 2014. During this period, the number of live newborns in Romania is estimated - according to national reference data at 4.7 million. The frequency of occurrence in specialized literature (1) for sensorineural deafness, genetic sensorineural deafness and congenital nonsyndromic sensorineural hearing loss (CNSHL) is: $1 / 500,1 / 700$ and $1 / 1000$ live newborns, respectively. In correlation with the number of live newborns, one can estimate that at present, in Romania the number of CNSHL patients aged 0 to 18 is approximately 4,700 . Using the same statistical methods presented in our previous study (2), maintaining the $95 \%$ probability score and the "confidence interval" of 22$44 \%$, we established the estimated size of the statistic sample population at 336 cases.

\section{Table 4. Prevalence of c.35delG and p.W24X mutations in Central and South-Eastern European countries}

\begin{tabular}{lcc}
\hline European country & $\begin{array}{c}\text { Prevalence of c.35delG } \\
\text { mutation in inherited } \\
\text { nonsyndromic deafness }\end{array}$ & $\begin{array}{c}\text { Prevalence of p.W24X } \\
\text { mutation in inherited } \\
\text { nonsyndromic deafness }\end{array}$ \\
\hline Croatia (8) & $55.85 \%$ & - \\
\hline Russia (9-11) & $42-57.5 \%$ & - \\
\hline Belarus (12) & $53 \%$ & $4.3 \%$ \\
\hline Austria (13) & $23.2 \%$ & $0.98 \%$ \\
\hline Bulgaria (14) & $43.1 \%$ & - \\
\hline Greece (15-16) & $26 \%-42 \%$ & - \\
\hline Czech Republic (17) & $40 \%$ & $4.3 \%$ \\
\hline Hungary (18) & $38 \%$ & - \\
\hline Poland (19) & $35.2 \%$ & - \\
\hline Cyprus (20) & $33.3 \%$ & - \\
\hline Slovenia (21) & $33 \%$ & $\mathbf{3 . 6 \%}$ \\
\hline Estonia (22) & $32.4 \%$ & $2.5 \%$ \\
\hline Romania [current study] & $\mathbf{2 7 . 3 \%}$ & \\
\hline Turkey (23-26) & $15-23.5 \%$ & \\
\hline
\end{tabular}


Based on the above presented data, we have been able to affirm that the sample lot of 179 patients is statistically significant.

With regards to the mutations $c .35 \mathrm{del} G$ and $p . W 24 X$ of gene GJB2, current studies in Central, Eastern and Southern Europe (Table 4) reflect a significant variability from one country to another, depending on ethnic particularities and sample size.

In the light of the results of our study, the frequency of occurrence for Romania is estimated at $27.3 \%$ for c. $35 \mathrm{del} G$ and $3.7 \%$ for $p . W 24 X$ (as compared to $33.3 \%$, and $5.3 \%$ respectively in our prior study-2). Data obtained is comparable to data obtained in the other countries located within our geographical region.

Table 5 resumes the information published before our study in the Pubmed database referring to the frequency of occurrence of the two most frequent mutations of gene GJB6. According to the studies reporting gene GJB6 mutations, the genotypes of patients suffering from hearing loss were in compound heterozygous form.

In Romania, there are only two research studies which have explored the presence of GJB6 mutations, one with 45 patients with hearing loss and having a cochlear implant (38) and the other one with 350 pregnant women without hearing impairment (39). None of the subjects within the two studies has been identified with $\operatorname{del}(G J B 6-$ D13S1830) or del(GJB6-D13S1854) mutations. A third observation on two Romanian children with hearing impairment revealed one compound heterozygous for the c.35delG/c.71G>A mutations and the other was homozygous for the c. $-23+1 G>$ A mutation (40). This second mutation was reported for the first time on a Romanian patient.

With regards to our sample group, we have genotyped the two deletions of GJB6 for all 179 patients; we have identified a female patient with genotype in heterozygous form $c .35 \mathrm{del} G+\operatorname{del}($ GJB6-D13S1830). From what we know, this is the first finding of a case diagnosed in Romania

Table 5. Prevalence of del (GJB6-D13S1830) and del (GJB6-D13S1854) mutations

\begin{tabular}{llcc}
\hline Country & $\begin{array}{l}\text { Number of } \\
\text { patients }\end{array}$ & $\begin{array}{c}\text { Prevalence of D-13S1830 } \\
\text { mutation in inherited } \\
\text { nonsyndromic deafness }\end{array}$ & $\begin{array}{c}\text { Prevalence of D13S1854 } \\
\text { mutation in inherited } \\
\text { nonsyndromic deafness }\end{array}$ \\
\hline France (27) & 256 & $5 \%$ & - \\
\hline Portugal (28) & 95 & $1.05 \%$ & - \\
$(29)$ & 264 & - & $0.76 \%$ \\
\hline Belarus (12) & 213 & $0.7 \%$ & - \\
\hline Germany (30) & 335 & $0.29 \%$ & 0 \\
\hline Italy (31) & 734 & $0.2 \%$ & - \\
\hline Slovakia (32) & 273 & 0 & - \\
\hline Austria (33) & 393 & 0 & 0 \\
\hline Croatia (34) & 63 & 0 & $0.65 \%$ \\
\hline Brazil (36) & 300 & $1 \%$ & - \\
\hline (36) & 77 & $0.65 \%$ & 0 \\
\hline Romania (38) & 77 & 0 & $\mathbf{0}$ \\
\hline Current study & 45 & 0 & - \\
\hline
\end{tabular}


which exhibits a mutation of gene GJB6. The frequency of occurrence of $\operatorname{del}($ GJB6D13S1830) was $0.28 \%$ (1/358 alleles tested). Mutation del(GJB6-D13S1854) lacked in all 179 patients.

Detection of the three mutations (two on GJB2 gene and one on GJB 6 gene) has allowed to establish the genetic cause for deafness in 45 patients, representing $25.14 \%$ of the trial cases. These patients were given a genetic counselling. In order to determine genetic causes, an analysis of other mutations shall be required in the case of the rest of the patients, by sequencing methods.

According to our data, our study is reporting the first case in Romania with a mutation of gene GJB6. It is also the largest sample of patients with congenital sensorineural deafness in proportion to the population of Romania. For an early tracking down of hearing loss and for an actual determination of the frequency of occurrence of the 4 mutations under analysis, the following are required: a genetic, audiological or combined screening in all maternity hospitals in Romania, the establishment of a national registry and the development of genetic centres where the above mentioned mutations could be determined.

A related cost and efficiency ratio shall determine the strategy to be implemented:

a. A general audiological screening followed by genetic tests in cases of deafness;

b. A universal genetic screening followed by the audiological examination of all patients suffering from mutations.

Also, any child whose hearing loss has no apparent cause must be genetically tested.

\section{Conclusions}

In our current study the determined prevalence for the three mutations was: $27.3 \%$ for $c .35 \mathrm{del} G$, $3.6 \%$ for $p . W 24 X$ and $0.28 \%$ for $\operatorname{del}(G J B 6$ D13S1830).
Those data are comparable to data obtained by the other European countries.

\section{Disclosure statement}

None of the authors of the said article has any conflicts of interests (financial or otherwise) with other institutions of private companies regarding the present clinical research.
Abbreviations
CNSHL = Congenital nonsyndromic sensorineural hearing loss
TOAE $=$ Acoustic otoemission

\section{References}

1. Snoeckx RL, Huygen PLM, Feldmann D, et al. GJB2 Mutations and Degree of Hearing Loss: A Multicenter Study. American Journal of Human Genetics. 2005;77(6):945-57. DOI: 10.1086/497996

2. Lazăr C, Popp R, Trifa A, Mocanu C, Mihut G, AlKhzouz C, et al. Prevalence of the c.35delG and p.W24X mutations in the GJB2 Gene in Patients with Nonsyndromic Hearing Loss from NorthWest Romania. Int J Pediatr Otorhinolaryngol. 2010 Apr;74(4):351-5. DOI: 10.1016/j.ijporl.2009.12.015

3. Simsek M, Al-Wardy N, Al-Khayat A, Al-Khabory M. A polymerase chain reaction-restriction fragment length polymorphism (PCR-RFLP) test to detect the common mutation (35delG) in the connexin-26 gene. Genet Test. 2002, 6(3):225-8. DOI: 10.1089/109065702761403414

4. RamShankar M, Girirajan S, Dagan O, Ravi Shanker H.M, Jalvi R, Rangasayee R, et al. Contribution of connexin 26 (GJB2) mutations and founder effect to non-syndromic hearing loss in India. J Med Genet. 2003 May;40(5):e68 doi:10.1136/jmg.40.5.e68. DOI: 10.1136/jmg.40.5.e68

5. Scott DA, Kraft ML, Carmi R, Ramesh A, Elbedour $\mathrm{K}$, Yairi $\mathrm{Y}$, et al. Identification of mutations in the connexin 26 gene that cause autosomal recessive nonsyndromic hearing loss. Hum Mutat. 1998;11(5):387-94. DOI: $10.1002 /(S I C I) 1098-1004(1998) 11: 5<387:: A I D-$ HUMU6>3.0.CO;2-8 
6. del Castillo FJ, Rodriguez-Ballesteros M, Alvarez A, T Hutchin, Leonardi E, de Oliveira CA, et al. A novel deletion involving the connexin-30 gene, del(GJB6- D13S1854), found in trans with mutations in the GJB2 gene (connexin-26) in subjects with DFNB1 non-syndromic hearing impairment. J Med Genet. 2005 Jul;42(7):588-94, DOI: 10.1136/jmg.2004.028324

7. Rodriguez-Paris J, Tamayo ML, Gelvez N, Schrijver I. Allele-specific impairment of GJB2 expression by GJB6 deletion del(GJB6-D13S1854). PLoS One. 2011; 6(6):e21665. DOI: 10.1371/journal.pone.0021665

8. Sansović I, Knezević J, Matijević T. Prevalence of the $35 \mathrm{delG}$ mutation in the GJB2 gene of patients with nonsyndromic hearing loss from Croatia. Genet Test. 2005 Winter;9(4):297-300. DOI: 10.1089/gte.2005.9.297

9. Markova TG, Poliakova AV, Kunelskaia NL. Clinical picture of hearing defects caused by $\mathrm{Cx} 26$ gene mutations.Vestn Otorinolaringol. 2008;(2):4-9.

10. Barashkov NA, Dzhemileva LU, Fedorova SA, Maksimova NR, Khusnutdinova EK. Connexin gene 26 (GJB2) mutations in patients with hereditary non-syndromic sensorineural loss of hearing in the Republic of Sakha (Yakutia). Vestn. Otorinolaringol. 2008;(5):23-8.

11. Lalaiants MR, Bliznets EA, Markova TG, Poliakov AV, Tavartkiladze GA. The results of audiological examination of children presenting with sensorineural loss of hearing due to GJB2 gene mutations during the first year of life. Vestn Otorinolaringol. 2011;(3):31-5.

12. Danilenko N, Merkulava E, Siniauskaya M, Olejnik O, Levaya-Smaliak A, Kushniarevich A, et al. Spectrum of genetic changes in patients with non-syndromic hearing impairment and extremely high carrier frequency of 35 delG GJB2 mutation in Belarus. PLoS One. 2012;7(5):e36354. DOI: 10.1371/journal. pone. 0036354

13. Frei K, Szuhai K, Lucas T, Weipoltshammer K, Shofer $\mathrm{C}$, Ramsebner $\mathrm{R}$, et al. Connexin 26 mutations in cases of sensorineural deafness in eastern Austria. Eur J Hum Genet. 2002 Jul;10(7):427-32. DOI: 10.1038/ sj.ejhg.5200826

14. Popova DP, Kaneva R, Varbanova S, Popov TM. Prevalence of GBJ2 mutations in patients with severe to profound congenital non-syndromic sensorineural hearing loss in Bulgarian population. Eur Arch Otorhinolaryngol. 2012 Jun;269(6):1589-92. DOI: 10.1007/s00405-011-1817-2
15. Iliadou V, Eleftheriades N, Metaxas AS. Audiological profile of the prevalent genetic form of childhood sensorineural hearing loss due to GJB2 mutations in northern Greece. Eur Arch Otorhinolaryngol. 2004 May;261(5):259-61. DOI: 10.1007/s00405-003-0679-7

16. Kokotas H, Van Laer L, Grigoriadou M, Iliadou V, Economides J, Pomoni S, et al. Strong linkage disequilibrium for the frequent GJB2-35delG mutation in Greek population. Am J Med Genet A. 2008 November, Volume 146A, (22): 2879-84. DOI: 10.1002/ ajmg.a.32546

17. Seeman P, Malíková M, Rasková D, Bendova O, Groh D, Kubalkova M, et al. Spectrum and frequencies of mutations in the GJB2 $(\mathrm{Cx} 26)$ gene among 156 Czech patients with pre-lingual deafness. Clin Genet. 2004 Aug;66(2):152-7. DOI: 10.1111/j.13990004.2004.00283.x

18. Tóth T, Kupka S, Haack B. GJB2 mutations in patients with non-syndromic hearing loss from Northeastern Hungary. Hum. Mutat. 2004, 23:631-2. DOI: 10.1002/ humu. 9250

19. Wiszniewski W, Sobieszczanska-Radoszewska L, Nowakowska-Szyrwinska E, Obersztyn E, Bal J. High frequency of GJB2 gene mutations in Polish patients with prelingual nonsyndromic deafness. Genet Test. 2001 Summer;5(2):147-8. DOI: $10.1089 / 109065701753145637$

20. Neocleous V, Portides G, Anastasiadou V, Phylactou LA. Determination of the carrier frequency of the common GJB2 (connexin-26) 35delG mutation in the Greek Cypriot population. Int J Pediatr Otorhinolaryngol. 2006 Aug;70(8):1473-7. DOI: 10.1016/j.ijporl.2006.03.014

21. Medica I, Rudolf G, Prpić I. Incidence of the c.del35G/ GJB2 mutation in Croatian newborns with hearing impairment. Med Sci Monit. 2005, 11(11):533-5.

22. Teek R, Kruustük K, Zordania R, Joost K, Reimand T, Möls T, et al. Prevalence of c.35delG and p.M34T mutations in the GJB2 gene in Estonia. Int J Pediatr Otorhinolaryngol. 2010 Sep;74(9):1007-12. DOI: 10.1016/j.ijporl.2010.05.026

23. Uyguner O, Emiroglu M, Uzumcu A, Hafiz G, Ghanbari A, Baserer N, et al. Frequencies of gap and tight-junction mutations in Turkish families with autosomal- recessive non-syndromic hearing loss. Clin Genet. 2003, 64 (1):65-9. DOI: 10.1034/j.1399-0004.2003.00101.x 
24. Tekin M, Arici ZS. Genetic epidemiological studies of congenital/prelingual deafness in Turkey: population structure and mating type are major determinants of mutation identification. Am J Med Genet A. 2007 Jul 15;143A(14):1583-91. DOI: 10.1002/ajmg.a.31702

25. Evirgen N, Solak M, Dereköy S, Erdoğan M, Yildiz H, Eser B, et al. Genotyping for $\mathrm{Cx} 26$ and $\mathrm{C} \times 30$ mutations in cases with congenital hearing loss. Genet Test. 2008 Jun;12(2):253-6. DOI: 10.1089/gte.2007.0106

26. Baysal E, Bayazit YA, Ceylaner S, Alatas N, Donmez B, Ceylaner G, et al. GJB2 and mitochondrial A1555G gene mutations in nonsyndromic profound hearing loss and carrier frequencies in healthy individuals. J Genet. 2008 Apr;87(1):53-7. DOI: 10.1007/s12041-008-0007-5

27. Marlin S, Feldmann D, Blons H, Loundon N, Rouillon I, Albert S, et al. GJB2 and GJB6 mutations genotypic and phenotypic correlations in a large cohort of hearing-impaired patients. Arch Otolaryngol Head Neck Surg. 2005 Jun;131(6):481-7. DOI: 10.1001/archotol.131.6.481

28. Nogueira C, Coutinho M, Pereira C, Tessa A, Santorelli FM, Vilarinho L. Molecular investigation of pediatric Portuguese patients with sensorineural hearing loss. Genet Res Int. Volume 2011 (2011). DOI: $10.4061 / 2011 / 587602$

29. Matos TD, Simões-Teixeira H, Caria H, Gonçalves AC, Chora J, Correia M, et al. Spectrum and frequency of GJB2 mutations in a cohort of 264 Portuguese nonsyndromic sensorineural hearing loss patients. Int J Audiol. 2013,52:466-71.DOI: 10.3109/14992027.2013.783719

30. Bartsch O, Vatter A, Zechner U, Kohlschmidt N, Wetzig C, Baumgart A, et al. GJB2 mutations and genotype-phenotype correlation in 335 patients from Germany with nonsyndromic sensorineural hearing loss: evidence for additional recessive mutations not detected by current methods. Audiol Neurootol. 2010, 15:375-82. DOI: 10.1159/000297216

31. Primignani P, Trotta L, Castorina P, Lalatta F, Sironi F, Radaelli C, et al. Analysis of the GJB2 and GJB6 genes in Italian patients with nonsyndromic hearing loss: frequencies, novel mutations, genotypes, and degree of hearing loss. Genet Test Mol Biomarkers. 2009 Apr;13(2):209-17. DOI: 10.1089/gtmb.2008.0086

32. Minárik G, Tretinárová D, Szemes T, Kádasi L. Prevalence of DFNB1 mutations in Slovak patients with non-syndromic hearing loss. Int J Pediatr Otorhinolaryngol. 2012 Mar;76(3):400-3. DOI: 10.1016/j.ijporl.2011.12.020
33. Günther B, Steiner A, Nekahm-Heis D, Albegger $\mathrm{K}$, Zorowka P, Utermann G, et al. The 342-kb deletion in GJB6 is not present in patients with non-syndromic hearing loss from Austria. Hum Mutat. 2003 Aug;22(2):180. DOI: 10.1002/humu.9167

34. Medica I, Rudolf G, Balaban M, Peterlin B. C.35delG/ GJB2 and del(GJB6-D13S1830) mutations in Croatians with prelingual non-syndromic hearing impairment. BMC Ear, Nose and Throat Disord. 2005, Dec 8; 5:11. DOI: $10.1186 / 1472-6815-5-11$

35. Batissoco AC, Abreu-Silva RS, Braga MC, Lezirovitz K, Della-Rosa V, Alfredo T Jr, et al. Prevalence of GJB2 (connexin-26) and GJB6 (connexin-30) mutations in a cohort of 300 Brazilian hearing-impaired individuals: implications for diagnosis and genetic counseling. Ear Hear. 2009 Feb;30(1):1-7. DOI: 10.1097/ AUD.0b013e31819144ad

36. Cordeiro-Silva M de F, Barbosa A, Santiago M, Provetti M, Dettogni RS, Tovar TT et al. Mutation analysis of GJB2 and GJB6 genes in Southeastern Brazilians with hereditary nonsyndromic deafness. Mol Biol Rep. 2011, February, (2) 38:1309-13. DOI: 10.1007/s11033010-0231-y

37. Castro LS, Marinho AN, Rodrigues EM, Marques GC, Carvalho TA, Silva LC, et al. A study of GJB2 and delGJB6-D13S1830 mutations in Brazilian non-syndromic deaf children from the Amazon region. Braz J Otorhinolaryngol. 2013, Feb; 79(1):95-9. DOI: 10.5935/1808-8694.20130016

38. Rădulescu L, Mârţu C, Birkenhäger R, Cozma S, Ungureanu L, Laszig R. Prevalence of mutations located at the DFNB 1 locus in a population of cochlear implanted children in eastern Romania. Int $\mathrm{J}$ Pediatr Otorhinolaryngol. 2012, Jan;76(1):90-4. DOI: 10.1016/j.ijporl.2011.10.007

39. Dragomir C, Stan A, Stefanescu DT, Savu L, Severin E. Prenatal screening for the $35 \mathrm{delG} / \mathrm{GJB} 2$, del (GJB6-D13S1830), and del (GJB6-D13S1854) mutations in the Romanian population. Genet Test Mol Biomarkers. 2011 Nov, 15 (11):749-53. DOI: 10.1089/ gtmb.2011.0048

40. Dragomir C, Ionescu Ionescu A, Savu L, Severin E. Detection of the GJB2 gene mutations in two children with hearing impairment. Rev Romana Med Lab. 2015;23(4):495-9. DOI: 10.1515/rrlm-2015-0047 